\title{
Point Mutation Leu1014Phe (voltage-gated sodium channel/VGSC) gene in Aedes aegypti (L.) as Insecticide Resistance Marker Synthetic Pyrethroid in Palembang, Indonesia
}

\author{
Chairil Anwar, ${ }^{1 *}$ Abu Umayah, ${ }^{1}$ Ahmad Ghiffari, ${ }^{2,3}$ Ulrich Kuch, ${ }^{3}$ Yulian Taviv, ${ }^{4}$ Nurlela, ${ }^{5}$ Mgs.Irsan \\ Saleh $^{1}$
}

\begin{abstract}
Aedes aegypti is a vector of several pathogens including dengue fever/dengue hemorrhagic fever virus. Five hundred thousand dengue hemorrhagic fever new cases occur every year throughout the world. Vector control is an effective way to break the transmission; unfortunately constant insecticide used caused resistance. The purpose of research was to identify the Leu1014Phe point mutation in the VGSC gene of Ae.aegypti in Palembang. Population were all 3rd and 4th instar larvae of Ae.aegypti derived from breeding eggs obtained from villages of Bukit Kecil, Ilir Timur I and Sukarami sub district. Results showed that there has been Leu1014Phe point mutation. It can be concluded that synthetic pyrethroid insecticides resistance in Palembang on its Ae.aegypti was due to the target site mechanism.
\end{abstract}

Index Terms-Aedes aegypti, insecticide resistance, Leu1014Phe, point mutation VGSC gen, target site mechanism

\section{INTRODUCTION}

$A$ edes aegypti is a vector of various pathogens, including dengue virus. The fatal form of dengue is dengue shock syndrome (DSS) in children. It is estimated that approximately 2,5 billion people at risk of infection with dengue cases per year [1]. In 2011, the total dengue cases in all provinces in Indonesia reached 26,015, with as many as 389 deaths $(\mathrm{CFR}=1,53 \%)$, and in Palembang incidence rate stood at $49.68 \%$. With 3 highest incidence of cases in the district Ilir Timur I (IR=90.77\%), Bukit Kecil districts $(I R=79,89 \%)$ and Sukarami subdistrict $(68,31 \%)$ [2].

Until now there is no treatment nor vaccine to prevent dengue fever, and vector control is the best way to break the chain of transmission. Dengue prevention efforts have been applied such as the use of insecticides through fogging

Chairil Anwar ${ }^{1}$ is with Sriwijaya University, South Sumatra, Indonesia Abu Umayah ${ }^{1}$ is with Sriwijaya University, South Sumatra, Indonesia

Ahmad Ghiffari ${ }^{2,3}$ is with Department of Medicine, Frankfurt University and also work with Muhammadiyah Palembang University, South Sumatra, Indonesia

Ulrich $\mathrm{Kuch}^{3}$, is with the Department of Medicine, Frankfurt University, Germany

Yulian Taviv ${ }^{4}$ is with Loka Litbang Baturaja, Indonesian Ministry of Health, South Sumatra Indonesia

Nurlela ${ }^{5}$, works in General Hospital of Prabumulih Municipality, South Sumatra Province, Jl. Lingkar Kel. Gunung Ibul, 31111 Prabumulih Timur, Indonesia

Mgs Irsan Saleh ${ }^{1}$ is with Sriwijaya University, South Sumatra, Indonesia technique, abatization and mosquito nest eradication. Unfortunately incidence rate of last few years were yet high and there have been several dengue outbreaks [3]. Resistance can occur due to the constant use of the insecticides intensively for a long time [4]. Insecticides resistance in Ae.aegypti can easily widespread throughout the world. Starting from the dichloro diphenyl trichloroetane (DDT) in the Caribbean in 1955 and Thailand [5]. Resistance also occurs in synthetic pyrethroids in Brazil [6], Thailand [7], and Indonesia [8].

Three ways on how to detect synthetic pyrethroid resistance are bioassay, biochemistry and molecular test. Biochemical detection mechanism is to detect elevated levels of enzymes that detoxify insecticides (metabolic resistance). The enzymes that often used as a marker of change include cytochrome P450 monooxygenases (P450s) [9]), glutathione S-transferases (GSTs) [10] and carboxy/cholinesterases (CCES) [11]. Further investigation discovered that there was incidence of resistance in the absence of increase biochemical detoxification enzyme [12], suggesting experts to explore deeper mechanism behind the resistance using molecular test. The test detected that the synthetic pyrethroid resistance was due to the point mutations on voltage-gated sodium channels gene as the target site where the insecticide could bind (resistance targets) [13].

In previous Palembang city monitoring vector control program, biochemical test on Ae.aegypti turn out normal level despite incidence rate of dengue were high enough [14]. The molecular studies was necessary to applied as it can detect gene mutations (VGSC), whilst the decrease of target site sensitization can caused insecticide resistance.

\section{MATERIAL AND METHODS}

\section{A. Genetic Material}

Population were all $3^{\text {rd }}$ and $4^{\text {th }}$ instar larvae of Ae.aegypti derived from breeding eggs which obtained since July 2012 until August 2013 from local residents of Bukit Kecil, Ilir timur I and Sukarami sub distric. Identification took place in Balai Besar Laboratorium (BBLK) Palembang while molecular test took place both in BBLK and Clinical Microbiology Department of Muhammad Hoesin Hospital Palembang. 


\section{B. DNA Extraction}

DNA was extracted from whole larva body. DNA was then extracted using a procedure of Promega Wizard Purification protocol [14]. A total of $0,02 \mathrm{~g}$ from each pool was grounded thoroughly on mortar and then transfer into universal tube containing $600 \mathrm{ul}$ of nuclei lysis solution. The tube was gently agitated and incubated with 17,5 ul of protein kinase $C$ at $65^{\circ} \mathrm{C}$ for $15-30$ minutes. Then $3 \mathrm{~mL}$ RNAase solution was added and homogenized, later incubated at $37^{\circ} \mathrm{C}$ for 30 minutes. Next $200 \mathrm{~mL}$ precipitation of protein solution was added, agitated, cooled for 5 minutes and centrifugated in $13.000 \mathrm{rpm}$ for 4 minutes. Supernatant was transferred into the tube containing $600 \mathrm{~mL}$ isopranol. The tube was gently stirred until the white thread is formed. Then the tube was centrifugated in 13,000 rpm at room temperature for 1 minute. Next the supernatant was discarded, and transfer to a tube containing cool 70\% ethanol. Later the tube was centrifugated $13,000 \mathrm{rpm}$ at room temperature for 1 minute. The extracted DNA pellet was resuspended with $100 \mathrm{~mL}$ solution of DNA dehydration. RNase was inactivated by heating at $65^{\circ} \mathrm{C}$ for 1 hour. The preparation of the semi-nested PCR was conducted in two steps. The first step was pre-amplification to produce DNA template. And the second step was selective amplification (RFLP) to produce specific fragment that will be appeared on electrophoresis gel.

\section{C.DNA Mix Preparation}

The composition of first step $25 \mu 1$ are $7,5 \mu 1 \mathrm{ddH} 2 \mathrm{O} ; 10 \mu \mathrm{l}$ Go tag green (dATP, dCTP, dGTP, dTTP, $\mathrm{MgCl} 2$ and Taq polymerase); @0,5 $\mu 1$ Primer AgF_Kdr and An_Kdr_R2 and 5 $\mu 1$ DNA template. And the second composition of first step of $25 \mu \mathrm{l}$, are 7,5 $\mu \mathrm{lddH} 2 \mathrm{O} ; 10 \mu \mathrm{l}$ Go tag green (dATP, dCTP, dGTP, dTTP, $\mathrm{MgCl} 2$ and Taq polymerase); @0,5 $\mu 1$ Primer AgF_Kdr and Ag_R_Kdr and $5 \mu \mathrm{l}$ DNA template.

The composition of second step consist of $12 \mu \mathrm{l}$ are $2,6 \mu \mathrm{l}$ ddH2O; $1,2 \mu \mathrm{l}$ buffer, $0,2 \mu \mathrm{l}$ restriction enzyme $8 \mu \mathrm{l}$ amplicon.

\section{D.DNA Fragment Amplification}

Fragment gene was amplified by PCR using sequence primers:

- AgF kdr was 5'GACCATGATCTGCCAAGATGGAAT5'; - An kdr R2 was : 5'GAGGATGAACCGAAATTGGACA3'; - Agr kdr 5'GCAAGGCTAAGAAAAGGTTAA GCA3';.

Preamplification to produce DNA template was using PCR Thermal $\mathrm{Cycler}^{\circledR}$ apparatus set up for pre-denaturation and denaturation cycles. Pre-denaturation cycles was a set up of 5 minutes of initial denaturation step at $94^{\circ} \mathrm{C}, 5$ minutes denaturation step at $94^{\circ} \mathrm{C}, 30$ seconds annealing step $51^{\circ} \mathrm{C}$ and 90 seconds elongation at $72^{\circ} \mathrm{C}$. Denaturation cycles was a setup of 29 cycles of 30 seconds denaturation step at $94^{\circ} \mathrm{C}, 30$ seconds annealing at $51^{\circ} \mathrm{C}$, and 60 seconds elongation $72^{\circ} \mathrm{C}$, finally the last stage of additional extension phase 7 minutes at $72^{\circ} \mathrm{C}$. And the amplicon was being again preamplified with the second step mixing component, with following predenaturation and denaturation cycles as follow. Predenaturation cycles was a set up of 5 minutes of initial denaturation step at $94^{\circ} \mathrm{C}, 5$ minutes denaturation step at $94^{\circ} \mathrm{C}, 30$ seconds annealing step $57^{\circ} \mathrm{C}$ and 60 seconds elongation at $72^{\circ} \mathrm{C}$. Denaturation cycles was a setup of 39 cycles of 30 seconds denaturation step at $94^{\circ} \mathrm{C}, 30$ seconds annealing at $57^{\circ} \mathrm{C}$, and 40 seconds elongation $72^{\circ} \mathrm{C}$, finally the last stage of additional extension phase 7 minutes at $72^{\circ} \mathrm{C}$.

\section{E. Data Analysis}

Gel Doc $1000^{\circledR}$ (Biorad USA) provided, as output, an image of DNA fragment bands of electrophoresis gel. The bands was interpretated and scored using software; the presence of band was scored as one (1) and the absence was scored as zero (0), and the data were transferred to figure to be determined for analysis.

\section{RESULTS}

\section{A. RFLP Loci}

RFLP (restriction fragment length polymorphism) analyzed of forty five loci from total sub districts revealed by size of DNA bands consisting of the fragment of $138 \mathrm{bp}$ and $61 \mathrm{bp}$.

\section{B. Correlation and Analyses}

Positive point mutation in the gene Leu1014Phe expressed with a band with a length of $138 \mathrm{bp}$ and $91 \mathrm{bp}$ after the RFLP, while wild-type (susceptible) DNA will not be cutted by the both restriction enzymes.

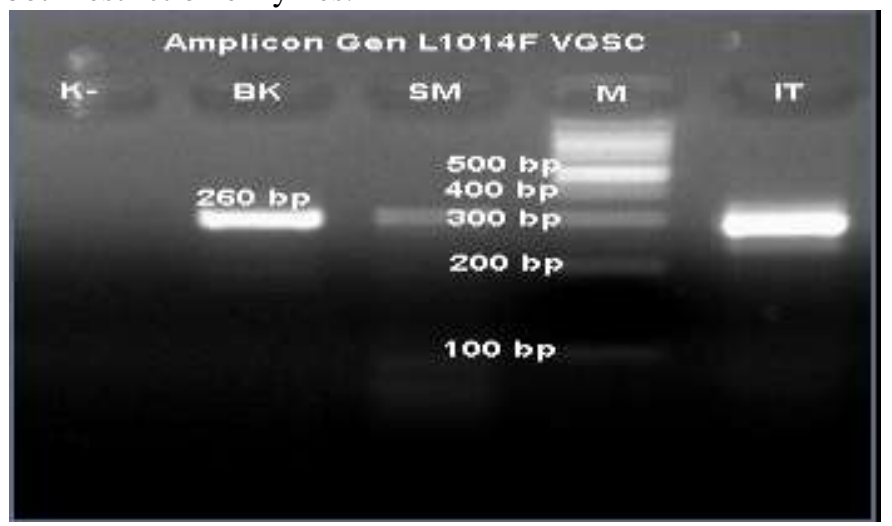

Picture 1. DNA fragment not yet cutted by RFLP enzyme

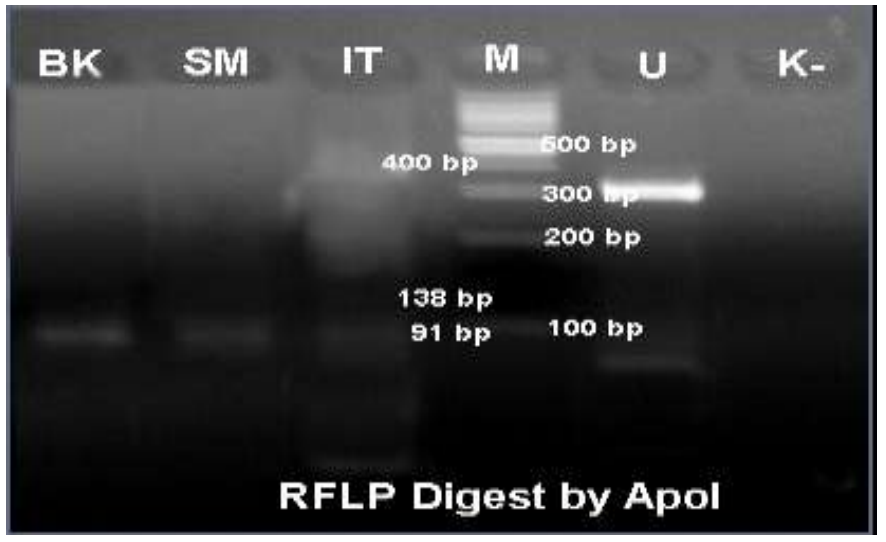

Picture 2. DNA fragment cutted by ApoI enzyme 


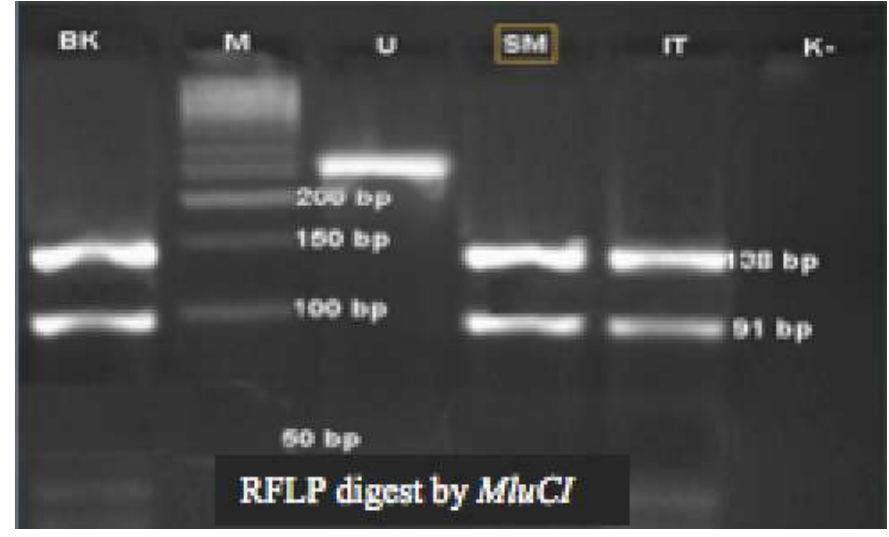

Picture 3. DNA fragment cutted by $\mathrm{MuCl}$ enzyme

\section{DISCUSSION}

Synthetic pyrethroid insecticide works on the nervous system of insects that inhibit axon on ion channels resulting in a continuous action potential [15]. Synthetic pyrethroid binds in of voltage-gated sodium channel (VGSC) that regulate nerve impulses rate. As a result, nerve impulses will undergo continuous stimulation and lead the insect to hyper excitability and convulsions.

Molecular ways on detection of synthetic pyrethroid insecticide resistance known in two ways: detoxification enzyme changes and changes in the target site, voltage-gated sodium channel (VGSC). Detection of detoxification enzymes detect the point mutations in the gene that can cause increased levels of enzymes that detoxify insecticides (metabolic resistance).

Three enzymes associated with insecticide detoxification cytochrome P450 monooxygenases (P450s) [9], glutathione Stransferases (GSTs) [10] and carboxy/cholinesterases (CCES) [16]. Detection of the target site resistance detects the point mutation in the gene that cause insecticide not to bind to VGSC. VGSC mutation was first identified in domain II S6 L1014F VGSC gene of Musca domestica, where the codon encoding leucine substituted by fenilalanin [17].

First molecular synthetic pyrethroid insecticide resistance research in Palembang came out negative result on VGSC gene point mutations [18]. The point mutation which examined was F1534C, the same gene mutation that expressed in case of insecticide resistance of Ae.aegypti from Cayman Island [19]. Until now there had been 26 point mutations found which associated with resistance VGSC in various different point, and seven points on known gene mutations occur in Ae.aegypti, are: (1) Ile1011Met; ATA encoding isoleucine at codon changed into ATG [16]; (2) Ile1011Val, ATA at codon encoding isoleucine turned into GTA [12]; (3) F1552C, TTC at codon encoding alanine phenyl turned into TGC [20,21]; (4) F1534C, TTC at codon encoding alanine phenyl turned into TGC [19]; (5) Val1023Gly, codon encoding valine turned into glycine [22]; (6) Val1016Gly, codon encoding valine turned into glycine [23]; (7) F1023C, TTC at codons encoding phenylalanine turns into TGC [24].

Continued research in biomolecular insecticide resistance in Palembang proceed with other point mutation, Leu1014Phe, found in the population of Ae.aegypti in Brazil and Anopheles aconitus in Lampung [25]. Positive point mutation in the gene Leu1014Phe expressed with a band with a length of $138 \mathrm{bp}$ and $91 \mathrm{bp}$ after the RFLP, while wild-type (susceptible) will not showed the two DNA fragment.

\section{V.CONCLUSION}

From the molecular resistance diagnostic tests on the VGSC gene mutations on Leu1014Phe founded that, the insecticide resistance mechanisms was the decreseased sensitivity of targets site. This study provides an alternative diagnostic test on synthetic pyrethroid insecticide resistance, especially in areas with a high incidence of dengue but negative result on biochemical insecticide resistance tests.

\section{ACKNOWLEDGMENT}

This study was supported by Hibah Unggulan Perguruan Tinggi research grant of the Directorate General of Higher Education Ministry of Education and Culture, Indonesia. The authors thank to Sriwijaya University and the Directorate General of Higher Education for the awarded grant. We also thank to Venny Patricia for DNA preparation and laboratory supports.

\section{REFERENCES}

[1] WHO. 2011. Accessed at: http://www.who.int/csr/disease/dengue /impact/en/

[2] Dinkes Kota Palembang. 2012. Laporan Tahunan Dinas Kesehatan Kota Palembang, Diakses dari: http://dinkes.palembang.go.id/tampung dokumen/dokumen-56-57.pdf

[3] Kementerian Kesehatan RI, Dirjen PP \& PL. 2010. Peraturan Menteri Kesehatan RI tentang Pengendalian Vektor. Nomor: 374/Menkes/PER/III/2010.

[4] WHO. 1992. Vector Resistance to Pesticides. Fifteenth Report of the WHO Expert Committee on Vector Bioogy and Control.

[5] Ponlawat A, Scott JG, and Harrington LC. 2005. Insecticide Susceptibility of Aedes aegypti and Aedes albopictus Across Thailand. J. Med. Entomol. 42(5): 821-825. http://dx.doi.org/10.1093/jmedent/42.5.821

[6] Da Cunha MP, Lima JBP, Brogdon WG, Moya GE, and Valle D. 2005. Monitoring of Resistance to the Pyrethroid Cypermethrin in Brazilian Aedes aegypti (Diptera: Culicidae) Population Collected Between 2001 and 2003. Mem Inst Oswaldo Cruz. 100: 441-444. http://dx.doi.org/10.1590/S0074-02762005000400017

[7] Paeporn P, Yaumphan P, and Supaphathom K. 2002. Insecticide Susceptibility and Selection for Resistance in A Population of Aedes aegypti from Ratchaburi Province, Thailand. National Institute of Health, Department of Medical Sciences, Ministry of Public Health, Nonthaburi, Thailand.

[8] Ahmad I, Astari S, and Tan M. 2007. Resistance of Aedes aegypti (Diptera: Culicidae) in 2006 to Pyrethroid Insecticides in Indonesia and its Association with Oxidase and Esterase Level. Pakistan J Biol Sci. 10 (20): 3688-3692. http://dx.doi.org/10.3923/pjbs.2007.3688.3692

[9] Daborn PJ, Yen JL, Bogwitz MR, Le Goff G, Feil E, Jeffers S, Tijet N, Perry T, Heckel D, and Batterham P. 2002. A single P450 allele associated with insecticide resistance in Drosophila. Science. 297:22532256. http://dx.doi.org/10.1126/science. 1074170

[10] Che Mendoza A, Penilla RP, and Rodriguez DA. 2009. Insecticide resistance and glutathione S-transferases in mosquitoes: A review. African Journal of Biotechnology. 8 (8): 1386-1397.

[11] Brengues C, Hawkes NJ, Chandre F, McCarroll L, Duchon S, Guillet P, Manguin S, Morgan JC, and Hemingway J. 2003. Pyrethroid and DDT cross-resistance in Aedes aegypti is correlated with novel mutations in 
the voltage-gated sodium channel gene. Medical and Veterinary

Entomology. 17: 87-94.

http://dx.doi.org/10.1046/j.1365-2915.2003.00412.x

[12] Saavedra-Rodriguez K, Strode C, Suares AF, Salas IF, Ranson H, Hemingway J, and Black WC. 2008. QTL mapping of genome regions controlling permethrin resistance in the mosquitoe Aedes aegypti. Genetics. 180:1137-1152.

http://dx.doi.org/10.1534/genetics.108.087924

[13] Salim M, Ambarita LP, and Yenni A, 2009. Efektivitas Malation dalam pengendalian vektor Demam Berdarah Dengue dan uji kerentanan larva Aedes aegypti terhadap Temefos di kota Palembang. Laporan Diseminasi Penelitian, Badan Penelitian dan Pengembangan Kesehatan Kementrian Kesehatan RI, Baturaja.

[14] Promega Wizard Purification. Accessed at http://worldwide.promega.com/ /media/ Files/Resources/Protocols/Technical\%20Manuals/0/Wizard\%20Genomi c\%20DNA\%20Purification\%20Kit\%20Protocol.pdf

[15] Soderlund DM, and Knipple DC. 2003. The Molecular Biology of Knockdown Resistance to Pyrethroid Insecticides. Insect Biochemistry and Molecular Biology. 33:563-577. http://dx.doi.org/10.1016/S0965-1748(03)00023-7

[16] Martins AJ, RMM de Andrade, JGB Linss, AA Peixoto, and D Valle. 2009. Voltage-Gated Sodium Channel Polymorphism and Metabolic Resistance in Pyrethroid-Resistant Aedes aegypti from Brazil. Am. J. Trop. Med. Hyg. 81(1): 108-115.

[17] Hollingworth RM, Dong K. 2008. Biochemical and Molecular Basis of Resistance. In: Global Pesticide Resistance in Arthropods; Whalon ME, Sanchez DM, Hollingworth RM (eds).. pp. 48-51. http://dx.doi.org/10.1079/9781845933531.0040

[18] Ghiffari A, and Fatimi H. 2011. Deteksi Mutasi Titik Gen Natrium Voltage Gated Channel Menggunakan Polymerase Chain Reaction pada Aedes aegypti Resisten Sintetik Piretroid di Palembang. Buletin Spirakel ed.2.. pp.17-24.

[19] Harris AF, Rajatileka S, and Ranson H. 2010. Pyrethroid Resistance in Aedes aegypti from Grand Cayman. Am. J. Trop. Med. Hyg. 83(2): $277-$ 284. http://dx.doi.org/10.4269/ajtmh.2010.09-0623

[20] Yanola J, Somboon P, Walton C, Nachaiwieng W, and Prapanthadara L. 2010. A Novel F1552/C1552 Point Mutation in The Aedes aegypti Voltage-Gated sodium Channel Gene Associated with Permethrin Resistance. Pesticide Biochemistry and Physiology. 96:127-131. http://dx.doi.org/10.1016/j.pestbp.2009.10.005

[21] Yanola J, Somboon P, Walton C, Nachaiwieng W, Somwang P, and Prapanthadara L. 2011. High Throughput Assays for Detection of The F1534C Mutation in The Voltage Gated Sodium Channel Gene in Permethrin Resistant Aedes aegypti and The Distribution of This Mutation throughout Thailand. Tropical Medicine and International Health. 16(4):501-509. http://dx.doi.org/10.1111/j.1365-3156.2011.02725.x

[22] Chang C, Shen WK, Wang TT, Lin YH, Hsu EL, and Dai SM. 2009. A novel amino acidsubstitution in a voltage-gated sodium channel is associated withknockdown resistance to permethrin in Aedes aegypti. Insect Biochem Mol Biol. 39:272-278. http://dx.doi.org/10.1016/j.ibmb.2009.01.001

[23] Srisawat R, Komalamisra N, and Eshita Y. 2010. Point Mutations in Domain II of the Voltage Gated Sodium Channel Gene in Deltamethrin Resistant Aedes aegypti (Diptera: Culicidae). Appl. Entomol. Zool, 45: 275-282. http://dx.doi.org/10.1303/aez.2010.275

[24] Kawada H, Higa Y, and Komagata O. 2009. Widespread Distribution of A Newly Found Point Mutation in Voltage-Gated Sodium Channel in Pyrethroid Resistant Aedes aegypti Populations in Vietnam. PloS Neglected Tropical Diseases. 3, 5271-5277 http://dx.doi.org/10.1371/journal.pntd.0000527

[25] Syafruddin D, Hidayati APN, Asih PBS, Hawley WA, Sukowati S, and Lobo NF. 2010. Detection of 1014F kdr mutation in four major Anopheline malaria vector in Indonesia. Malaria Journal 9:315. http://dx.doi.org/10.1186/1475-2875-9-315 